\title{
Export diversification and export performance by destination country
}

Ignacio del Rosal

Department of Applied Economics

University of Oviedo

Avenida del Cristo, s/n

33006, Oviedo, Spain

Email: irosal@uniovi.es

Telephone: +34 985104992

Fax: +34985103780

\begin{abstract}
The main focus of this paper is the relationship between export diversification and export performance. The key difference with respect to the previous literature is that export diversification is measured and related to export volume by destination country. The approach is empirical and an aggregate export demand setting is adopted to test the significance and influence of export diversification, measured via the Herfindahl index, on export performance by destination country. The econometric estimation is performed using export data for Spain to its partner countries for the period 1999-2011. The main finding is the positive relationship between Spanish export concentration and export performance by destination market. This finding is shown to be robust to several econometric specifications.
\end{abstract}

\section{KEYWORDS}

Export diversification, export performance, international trade, panel data

\section{JEL CLASSIFICATION}

$\mathrm{F} 14, \mathrm{C} 33$

\section{ACKNOWLEDGEMENTS}

I would like to thank the editor, Gulcin Ozkan, for her help and an anonymous Associate Editor and two anonymous referees for their comments and suggestions that substantially improved the paper. Financial support from the Consejería de Educación, Cultura y Deporte del Principado de Asturias, is gratefully acknowledged. 


\section{INTRODUCTION}

Export diversification has been the focus of recent trade papers, a literature that is mostly empirical. Although there have been several motivations to do so, concerns about the vulnerability of the less developed countries with poorly diversified exports may be highlighted. As richer countries have high levels of exports diversification, the study of the relationship between export diversification and stages of development has been a natural step in the literature. The seminal paper by Imbs and Wacziarg (2003) led the study of the relationship between diversification and per capita income. These authors found that sectoral diversification increases at early stages of development, but then, after a turning point in per capita income, diversification begins to decline. This inverted U-shaped pattern between sectoral diversification and per capita income was also found for exports by Klinger and Lederman (2004, 2006) and Cadot et al. (2011a). In contrast, other authors such as De Benedectis et al. (2009), Parteka (2010), Parteka and Tamberi (2013a, b) and Mau (2016) are more sceptical about the decline in export diversification. Methodological issues, such as the measurement of diversification, the method of estimation and the use of control variables may be useful to understand the different conclusions. Cadot et al. (2013) and Mau (2016) review this line of research.

A related branch of the literature specifically studies the determinants of export diversification, such as the recent papers by Dennis and Shepherd (2011), Cadot et al. (2011b), Minondo (2011) and Agosin et al. (2012). These papers, as well as the literature concerned with the relation of stages of development and diversification, consider the export diversification as an overall measure for a country versus the rest of world, i.e. without distinguishing by destination countries. Other papers like Amurgo-Pacheco and Pierola (2008) and Regolo (2013) also study the determinants of export diversification, though on a bilateral basis.

Various approaches have been taken in the literature to measure trade diversification, but two main types of measures are commonly used (Cadot et al. 2013). On the one hand, concentration indices like those of Herfindahl, Theil and Gini, taken from the industrial and income-distribution literatures, are used as aggregate and synthetic measures of diversification. It is worth noting that, as these are concentration indices, their interpretation as measures of diversification has to be inverse. In this sense, an increase in the Herfindahl index, for instance, indicates an increase in export concentration, which can be also understood as a reduction in export diversification. On the other hand, trade diversification has also been analysed via several definitions of extensive and intensive margins, mainly popularised by Hummels and Klenow (2005). Broadly speaking, the extensive margin usually refers to changes in the number of active bilateral relationships (encompassing new products and new markets), whereas the growth of trade volumes in existing trade relationships is related to the intensive margin. This paper focuses on the former type of indicators of export diversification/concentration, although extensive and intensive margins indicators in the vein of Hummels and Klenow (2005) will be resumed in the Discussion section.

There is also very little literature aimed at finding a direct relationship between export diversification and export performance. The most clear-cut precedents are the papers by Funke and Ruhwedel (2001, 2002), who implemented the same empirical specification in both papers with respect to two different groups of countries: 10 East Asian countries and 15 Organisation for Economic Cooperation and Development (OECD) countries, respectively. In an aggregate export demand setting, these authors studied the influence of export variety on export performance using dynamic panel econometrics. They found some evidence that product variety in exports, measured for each country versus the rest of the world, is positively related to export performance. More recently, Camanho and 
Romeu (2011) studied the influence of product and trading partner diversity on the export resilience of Latin American countries during the global financial crisis. These authors found some evidence that product diversification attenuated the trade collapse, although the same did not occur with geographical diversification.

The relationship between export diversification and stages of development is quite interesting, but has been widely covered in the literature. The determinants of export diversity have also attracted the attention of several papers. The present paper focuses instead on the more specific topic of the empirical relationship between export diversity and export performance. In particular, the papers by Funke and Ruhwedel $(2001,2002)$ constitute the point of departure. However, this paper focuses attention at a lower level of aggregation to explore a specific research question: what happens if export diversification is related to export performance by destinations? This question is obviously related to the papers by Funke and Ruhwedel and the immediate interest lies in ascertaining whether their conclusions hold when the analysis is carried out at the destination country level. With a more general scope, this question would be interesting for the literature studying the relationship between development and diversification and the determinants of export diversity, if the conclusions suggest that the analysis of diversification should be ideally disaggregated by destinations.

Consequently, the empirical approach of Funke and Ruhwedel (2001, 2002), based on an aggregate export demand setting in the vein of Goldstein and Khan (1985), is adopted here. However, instead of taking a group of exporting countries and studying whether their overall export variety influences their export performance, an exporter country case is used to investigate whether its export flows can be related to export diversification by destination country. The country study case will be Spain and its export flows to the great majority of its destination countries are analysed for the baseline sample period 1999-2007. The econometric analysis will thus be based on a panel in which the sections are the Spanish partner countries.

The main finding is the positive relationship between Spanish export concentration and export performance by destination market, a result that is robust to several econometric specifications within the empirical model. This result contrasts with the direct precedents of Funke and Ruhwedel $(2001,2002)$ and also with the closely related findings of Camanho and Romeu (2011). In some sense, a positive relationship between export concentration and performance might sound counterintuitive and contradictory to conventional wisdom. However, the key difference has to be stressed once more: export variety is usually measured via overall indicators that count the rest of the world as a unique partner, while in this paper export variety and performance is studied by destination country. A first observation is hence that an overall diversification indicator encompasses two complementary forms of diversification: new products and/or new markets. Stable product-level diversification is compatible with geographical diversification, so overall diversification may coexist with greater concentration within destination markets. In this regard, papers such as Evenett and Venables (2002), Brenton and Newfarmer (2007) and Beverelli et al. (2015) highlight the importance of geographical diversification in expanding export variety. A second observation refers to the importance of the intensification of existing trading relationships in the evolution of trade volumes. Recent papers such as Amurgo-Pacheco and Pierola (2008) and Easterly et al. (2009) document the importance of the intensive margin and the concentration of exports. At the very least, the results of this study suggest that overall export diversity needs to be measured distinguishing between product and geographical diversification if the analysis is not carried out at the destination country level. 
The rest of the paper is organised as follows. Section II describes the data used for empirical analysis and provides some descriptive facts. Section III describes the econometric methodology employed. Section IV presents the baseline results and summarizes a number of robustness checks. Finally, Section V discusses the results, while Section VI briefly concludes the paper.

\section{DATA AND DESCRIPTIVE EVIDENCE}

The main focus of this paper is the relationship between export diversification and export performance for the Spanish case, analysed by destination country. Two main sources of data are required: detailed trade data between Spain and its partners and economic data about the countries involved. Both sets of data are needed to construct the basic variables used in the empirical model to explain Spanish export performance, such as exchange rates and national incomes.

Spanish export data come from the Spanish Foreign Trade Statistics, an official database maintained by the Spanish Tax Agency's Customs and Tax Department. Based on customs records, it provides detailed information about trade flows between Spain and the rest of the world. This database collects detailed information about Spanish international trade. However, for the purposes of this study, only data related to the export value in euros, country of destination and product code were required.

In Spanish Foreign Trade Statistics, traded products are classified according to the 8-digit Combined Nomenclature (CN), a product classification created by the European Union (EU) in 1987 based on the 6-digit Harmonized System (HS), an international classification developed by the World Customs Organization. The CN currently comprises around 9,500 categories and is updated every year, continuously incorporating numerous changes, especially following a revision of the HS. The HS is updated every five years, so the changes in its approximately 5,000 categories are less frequent $^{1}$. The 8-digit CN classification used in the Spanish Foreign Trade Statistics can be easily collapsed into 6-digit HS codes, a more stable classification that will be the chosen option for the baseline estimations in this paper. Although the HS classification is certainly more stable, three different HS 'editions' (1996, 2002 and 2007) exist in the sample period of this study. In order to use a consistent classification over time, the United Nations Statistics Division (UNSD) provides conversion tables that allow the conversion of trade data reported in later versions of the HS to earlier versions. This means that the HS 1996 can be used as the benchmark product classification, comprising 5,113 product codes. The UNSD conversion tables are subsequently used to convert the trade data reported in the 2002 and 2007 HS editions into the 1996 HS version. Hereafter, HS refers to the HS 1996 edition.

The economic data on Spain and its country partners come from the World Bank's 'Open Data' database. The variables used in the empirical analysis will be subsequently explained in detail.

The sample period used in this paper was chosen in order to avoid structural changes that might upset the relationship between export performance and export diversification by destination market, the first delimitation being 1999-2011. In the former year, Spain fixed its exchange rate to the euro, as did the other original members of the Euro Area. The latter year was determined by the availability at the time of the study of definitive national economic data for a wide range of countries

\footnotetext{
${ }^{1}$ Methodological details about the CN and HS classification systems can be found, for example, in Eurostat $(2015,2016)$ and Yu (2008).
} 
in the World Bank database. However, the period 1999-2011 contains the so-called 'great collapse' of international trade, which occurred in 2008-2009 as a consequence of the financial crisis triggered by the bankruptcy of Lehman Brothers (see, for instance, Bems et al. 2013). For this reason, the baseline sample period will be 1999-2007 and the remaining years will be used for robustness analysis.

Spanish trade data and national economic data from the World Bank are gathered in a panel dataset that comprises Spain's importing countries. In fact, not all of Spain's destination markets are included, as there are some very small and/or remote countries with a very low number of exported products. For instance, in 1999 Spain exported 4,593 6-digit HS products to Portugal, but only 19 to Belize. Therefore, a sampling criterion based on the number of exported product lines was imposed in order to avoid very marginal countries like Belize, with extremely low export diversity. Only countries importing a minimum of 100 6-digit HS products from Spain were considered in the sample. This threshold of 100 products is not very restrictive. On the one hand, the figure represents approximately $2 \%$ of the number of 6-digit HS lines exported by Spain to the rest of the world in the sample period. On the other hand, the minimum of $100 \mathrm{HS}$ products leaves 116 countries in the sample, a set of countries that represents an average of $95.9 \%$ of the total value of Spanish exports in the benchmark sample period. Furthermore, this criterion of a minimum number of products will be tested in the robustness analysis carried out following the baseline estimations.

Thus, the sections in the panel dataset used in this paper comprise 116 countries to which Spain exports. The sample period for the baseline estimations is 1999-2007, and will be 1999-2011 in the extended case. The panel is unbalanced because there are lost observations due to the threshold of 100 HS products and the lack of availability of economic data for some countries in some years. Table A1 in the Appendix A shows the descriptive statistics, while Table A2 lists the countries in the sample.

Diversification measures are usually applied to analyse trade diversification from one country to the rest of the world, i.e. taking the group of destination markets as a whole. This paper, however, focuses on export diversification at the level of destination markets. To this end, export diversity is measured with a transparent, well-known statistic: the Herfindahl index $(\mathrm{H})$. This index is calculated for every destination country $i$ over the $j=1, \ldots, N$ exported product lines in the following way:

$H_{i}=\sum_{j=1}^{N}\left(\frac{X_{i j}}{X_{i}}\right)^{2}$

where $X_{i j}$ is the export value of product $j$ to country $i$, and $X_{i}=\sum_{j=1}^{N} X_{i j}$. The Herfindahl index thus sums the squared shares of export lines to country $i$ and ranges between $1 / N$ and 1 . Larger values of the index are associated with greater export concentration and hence lower export diversification, and vice versa ${ }^{2}$.

For the sake of illustration, Figure 1 plots the logarithm of Spanish exports versus the logarithm of the Herfindahl index, both at the destination country level. To focus on within-country patterns, both variables are purged of country fixed effects, i.e. the country mean is removed. Figure 1 is based on 968 country-year pairs for the benchmark sample 1999-2007. The figure shows a positive

\footnotetext{
${ }^{2}$ The Herfindahl index can be normalised, subtracting $1 / \mathrm{N}$ and dividing by $(1-1 / \mathrm{N})$, to range between 0 and 1 . However, this normalisation reduces the information about diversification, as the number of products is lost. In addition, there are other measures of diversification just as popular as the Herfindahl index, such as the Theil and Gini indices. These alternative measures will be resumed in the robustness analysis carried out following the baseline estimations.
} 
relationship between the Herfindahl index and exports, descriptive evidence that apparently contradicts the results from prior direct precedents.

[Fig. 1 here]

However, the above figure only can serve as preliminary evidence. A major concern that arises when performing a regression analysis on the plotted variables is the simultaneous determination of both variables, as the volume and diversity of Spanish exports to any destination country will be jointly determined. If this is the case, in a regression with the logarithm of exports acting as the response variable and the logarithm of the Herfindahl index acting as the regressor, the latter will be correlated with the error term, i.e. there will be a problem of endogeneity. The Ordinary Least Squares (OLS) estimator will be inconsistent and the results will not be useful.

The econometric model presented in the next section is able to deal with the endogeneity problem, as well as being capable of accommodating a suitable dynamic specification.

\section{ECONOMETRIC MODEL}

The main hypothesis to be tested is the influence of export variety on Spanish exports by destination country. The starting point is the empirical model used by Funke and Ruhwedel $(2001,2002)$, who employed an aggregate export demand setting in the vein of Goldstein and Khan (1985) (see also Sawyer and Sprinkle, 1996, 1999). Export variety is included in the model together with the usual arguments of the export demand function, namely the level of real income and the relative price index. The initial empirical model is thus:

$\mathrm{X}_{\text {it }}=\beta_{0}+\beta_{\mathrm{H}} \mathrm{H}_{\mathrm{it}}+\beta_{\mathrm{Q}} \mathrm{Q}_{\text {it }}+\beta_{\mathrm{Y}} \mathrm{Y}_{\text {it }}+\gamma_{\mathrm{t}}+\mu_{\mathrm{i}}+\varepsilon_{\mathrm{it}}$

where $X_{i t}$ is the Spanish export value to country $i$ in year $t, H_{i t}$ is the Herfindahl index, $Q_{i t}$ is the real exchange rate between Spain and country $i, Y_{i t}$ is the Gross Domestic Product (GDP) of destination country $i$ in real terms, $\gamma_{t}$ is a year-specific intercept and $\mu_{i}$ is a time-invariant country-specific effect. The time fixed effect controls for factors that are common across destination countries, such as business cycles or any other time-specific common factor. The country fixed effects account for sources of unobserved heterogeneity that are constant over time. They control for determinants such as distance, common borders, common language, and so on. As regards the error term, $\varepsilon_{i t}$, it is assumed to reflect unobserved competitiveness shocks of Spanish exports in market $i$ and year $t$. These unobserved competitiveness shocks will exhibit persistence over time and the error term, $\varepsilon_{i t}$, is assumed to follow an autoregressive process of order one, $\operatorname{AR}(1)$ :

$\varepsilon_{\mathrm{it}}=\rho \varepsilon_{\mathrm{it}-1}+\omega_{\mathrm{it}},|\rho|<1$

where $\omega_{i t}$ represents uncorrelated disturbance with mean zero and constant variance. As stated by Bond (2002), the dynamics per se are not the principal focus of attention in this econometric strategy, but rather it allows the consistent estimation of the parameters of interest $\left(\beta_{H}, \beta_{Q}, \beta_{Y}, \rho\right)$.

Solving for $\varepsilon_{i t}$ in (2) and inserting in (3) with the corresponding time-lag adjustment on the right side of the equation, the econometric model has the following dynamic representation:

$$
\begin{gathered}
X_{\text {it }}=\rho X_{i t-1}+\beta_{H} H_{i t}-\rho \beta_{H} H_{i t-1}+\beta_{Q} Q_{i t}-\rho \beta_{Q} Q_{i t-1}+\beta_{Y} Y_{i t}-\rho \beta_{Y} Y_{i t-1} \\
+(1-\rho) \beta_{0}+(1-\rho) \mu_{i}+\left(\gamma_{t}-\rho \gamma_{t-1}\right)+\omega_{i t}
\end{gathered}
$$


A more general representation of (4) is:

$\mathrm{X}_{\mathrm{it}}=\pi_{1} \mathrm{X}_{\mathrm{it}-1}+\pi_{2} \mathrm{H}_{\mathrm{it}}+\pi_{3} \mathrm{H}_{\mathrm{it}-1}+\pi_{4} \mathrm{Q}_{\mathrm{it}}+\pi_{5} \mathrm{Q}_{\mathrm{it}-1}+\pi_{6} \mathrm{Y}_{\mathrm{it}}+\pi_{7} \mathrm{Y}_{\mathrm{it}-1}+\beta^{*_{0}}+\mu^{*}{ }_{\mathrm{i}}+\gamma^{*}+\omega_{\mathrm{it}}$

where $\pi_{l}=\rho, \beta^{*}{ }_{0}=(1-\rho) \beta_{0}, \mu^{*}{ }_{i}=(1-\rho) \mu_{i}$ and $\gamma^{*}=\left(\gamma_{t} \rho \gamma_{t-1}\right)$. This representation is subject to the non-linear (common factor) restrictions $\pi_{3}=-\rho \beta_{H}, \pi_{5}=-\rho \beta_{Q}$ and $\pi_{7}=-\rho \beta_{Y}$.

The identification of the parameters of interest, i.e. the restricted parameter vector $\left(\beta_{H}, \beta_{Q}, \beta_{Y}, \rho\right)$ of the structural model [Equations (2) and (3)], can be achieved following a two-step procedure. In the first step, parameter estimates of the unrestricted model [Equation (5)] are obtained by a suitable estimator. Given these estimates, the common factor restrictions can be imposed and tested in the second step using a minimum distance procedure. In other words, the first-step estimates of the unrestricted parameters together with the common factor restrictions (that map the structural parameters into the unrestricted parameters) are used to obtain minimum distance estimates of the structural parameters. For further details, see, for instance, Blundell and Bond (2000) and Wooldridge (2010, Chapter 14).

The dynamic configuration of Equation (5) presents the immediate problem of the endogeneity of the lagged dependent variable, $X_{i t-1}$, as it is positively correlated with the country effects, $\mu^{*}{ }_{i}$. This means that the OLS estimator of $\rho$ will be biased upwards, whereas the Within Groups estimator will be biased downwards. Besides the problem of inclusion of the lagged dependent variable as regressor, the Herfindahl index should also be considered endogenous due to the joint determination of the level and variety of Spanish exports to any country of destination.

The Generalised Method of Moments (GMM) dynamic panel estimators have been specifically developed to deal with the econometric problems imposed by the inclusion of a lagged dependent variable and other endogenous regressors. In the so-called 'Difference GMM' estimator (Arellano and Bond 1991), the regression equation is first differenced to remove the country-specific effects and the endogenous regressors (hence in first differences) are then instrumented with their past observations in levels. However, when the autoregressive parameter $(\rho)$ is relatively high, the variables in levels are weak instruments for the same variables in differences. The 'System GMM' estimator, developed by Arellano and Bover (1995) and Blundell and Bond (1998), improves the efficiency and consistency of the Difference GMM by simultaneously estimating two equations, one in first differences with lagged levels as instruments (as the Difference GMM estimator does) and the other in levels with lagged differences as instruments.

Several specification tests are especially important in GMM panel estimators. First, the serial correlation test developed by Arellano and Bond (1991) tests the null hypotheses of no serial correlation in the idiosyncratic term. Second, the Hansen (1982) test for overidentifying restrictions checks the null hypotheses of joint validity of the instruments and can be used with robust variance estimates. A related test is the Difference-in-Hansen test to check the validity of a subset of instruments (see, for instance, Baum et al. 2003 for details). This test is useful to verify the validity of instruments in the levels equation in the System GMM estimator and to avoid the instrument proliferation problem (Roodman, 2009b), an important concern in GMM panel techniques.

\section{ESTIMATION RESULTS}

\section{IV.1 Baseline results}


Equation (5) is estimated with an unbalanced panel data set for 116 destination countries of Spanish exports over the period 1999-2007. The Spanish export value, $X_{i t}$, is in real terms and has been deflated using unit value indices for Spanish foreign trade drawn up by the Bank of Spain. The Herfindahl index, $H_{i t}$, was computed for every destination country using the 6-digit HS classification. The bilateral real exchange rate was computed using the formula: $Q_{i t}=E_{i t}\left(\frac{P_{S p}}{P_{i}}\right)$, where $E_{i t}$ is the price of the euro in the currency of country $i$ and $P_{S p}$ and $P_{i}$ are the GDP deflators of Spain and country $i$, respectively. An increase in $Q_{i t}$ lowers the competitiveness of Spanish exports in market $i$. Finally, $Y_{i t}$ is the real GDP of destination country $i$. All variables are introduced in Equation (5) in natural logarithms.

The parameters of the unrestricted model (5) are estimated with the pooled OLS, Within Groups (WG), Difference GMM and System GMM estimators. Although OLS and WG are biased estimators, they respectively provide upper and lower bounds for the autoregressive parameter (Bond, 2002). After each estimation, the common factor restrictions are imposed and tested and the restricted coefficients $\left(\beta_{\mathrm{H}}, \beta_{\mathrm{Q}}, \beta_{\mathrm{Y}}, \rho\right)$ are obtained via minimum distance estimation. The Delta method is used to compute standard errors ${ }^{3}$.

In the GMM estimations, the lagged dependent variable and the Herfindahl index are treated as endogenous variables. Two-step GMM estimators are used in all cases and the Windmeijer (2005) correction for the standard errors is implemented. To avoid instrument proliferation, a limited number of lags are used to instrument the endogenous variables. In particular, lags t- 2 to t- 4 are initially used as instruments in the first-differenced equation for the variables in levels. Only the first lag for the differenced instrument is used in the levels equation of the System GMM. All GMM estimations include year dummies and enter in the estimator, together with the exogenous regressors, as standard instruments.

[Table 1 here]

Table 1 reports the results of four regressions. The upper part of Table 1 shows the estimations results of the unrestricted model, whereas the lower part shows the structural coefficients obtained via minimum distance estimations. Column (1) shows the pooled OLS estimator, while column (2) shows the WG or fixed effects OLS estimator. Although the results from these estimators are not of special interest due to being biased, they do provide the bounds for the autoregressive coefficient: the OLS coefficient of the lagged dependent variable is 0.969 and the WG estimation yields a value of 0.393. All the regressors appear to be highly significant, with robust standard errors clustered by country in these two estimators. The null hypothesis of the validity of the common factor restrictions is rejected in the OLS and WG cases, at the 5\% and 10\% levels, respectively. The results from the Difference GMM estimator are shown in column (3) of Table 1. The estimated coefficient of the lagged dependent variable $(0.216)$ is lower than the WG estimate $(0.393)$ and has lower statistical significance (at the $10 \%$ level). Only the point estimates for the contemporaneous Herfindahl index and foreign GDP are significant, presenting the same sign as the OLS and WG estimates. The Arellano-Bond test shows no evidence of serial correlation, while the null hypothesis of joint validity of all instruments (47) is not rejected by the Hansen test (p-value 0.315). Given the low estimate of the coefficient of the lagged dependent variable, this is a surprising result and can be interpreted as

\footnotetext{
${ }^{3}$ All estimations are carried out using STATA 12. The GMM estimations are implemented using the xtabond2 package developed by Roodman (2009a). The common factor test and the minimum distance estimation are carried out using the md_ar1 code written by Mans Söderbom (www.soderbom.net).
} 
evidence of the poor performance of the Difference GMM estimator in small samples when the dependent variable exhibits high persistence. Otherwise, the data do not reject the common factor restrictions ( $p$-value 0.570). The real exchange rate and foreign GDP have the expected sign, while the most interesting result is that the Herfindahl index shows a positive effect on Spanish exports. This means that more concentrated Spanish exports (in terms of product lines) would be associated with a higher export value.

The results from the System GMM, shown in column (4) of Table 1, appear to be more robust. The lagged dependent variable has a coefficient estimate of 0.740, falling within the 0.393-0.969 range established by the OLS and WG estimators. The Herfindahl index and foreign GDP regressors show significant point estimates, whereas the contemporaneous and lagged real exchange rate have more imprecise estimations in the unrestricted model. Once again, the Arellano-Bond test shows no evidence of serial correlation. The number of instruments grows to 62 due to the additional moment conditions implied for the levels equation, but stays well below the number of countries: 116 . The Hansen test does not reject the exogeneity of the full instrument set (p-value 0.419), while the test for the validity of instruments in the levels equation, an important check for the System GMM estimator, is easily passed with a p-value on the Difference-in-Hansen test of 0.450 . The three common factor restrictions are clearly accepted by the data ( $p$-value 0.443 ), the estimates for the structural coefficients being significant and presenting the same signs as the other estimates. The elasticity of Spanish exports with respect to the real exchange rate is low, -0.126 , while the elasticity with respect to foreign GDP is 0.846 . The main interest lies in the sample estimate of $\beta_{\mathrm{H}}: 0.292$. As this variable is measured in log values as well, its interpretation is also straightforward as an elasticity: a 10\% increase in the Herfindahl index would be associated with a 2.9\% increase in Spanish exports.

Hence, the main result of this paper is the positive association between volume of exports and export concentration when analysed by destination country. This result would be related to the relevance of the intensive margin in explaining the evolution of trade flows, an issue that will be taken up again in the Discussion section.

The System GMM estimates, with instruments lagged t-2 to t-4 in the first-differenced equation, appear to be quite reasonable and this model is considered the benchmark specification. This System GMM model is re-estimated changing the lag length in order to test the sensitivity of the results to modifications in the instrument set (see the details in Appendix B). The overall impression from this exercise is that the System GMM estimates are robust to changes in the instrument set.

\section{IV.2 Robustness checks}

Several alternative specifications to test the robustness of the main results are considered next. These robustness checks are summarized in this subsection, but the details can be found in Tables $\mathrm{C} 1$ and $\mathrm{C} 2$ of Appendix C. The overall impression is that the main finding of this paper, i.e. the positive relationship between Spanish export concentration and export performance by destination country, is quite robust to several specifications.

Different sample period. The time span used in the baseline results is 1999-2007, mainly to avoid the effects of the trade collapse of 2008-09. The extension of the sample period to 1999-2011 expands the number of observations, but also increases the number of instruments. However, the results do not vary essentially. 
Different product classifications. The product classification used in the benchmark is the 1996 edition of the HS, at the 6-digit level of disaggregation. Spanish trade data reported in other HS editions were converted into the HS 1996 using the UNSD conversion tables. Insofar as the Herfindahl index is an aggregate index of concentration, it may be argued that this conversion is not strictly necessary, so the data originally reported in the current HS may be used instead. The results of the econometric model are virtually the same. A somewhat more demanding robustness check is to use the 8-digit $\mathrm{CN}$ product classification (CN8), applying the same logic, i.e. without making any conversion. The results are quite similar to the benchmark scenario.

Different number of products threshold. In order to avoid very marginal destination countries, the threshold of 100 HS products was established as a sample criterion. This threshold is changed in two opposing ways: reducing it to 50 HS products, and doubling it to $200 \mathrm{HS}$ products. The number of countries in the sample increases to 128 in the former case and decreases to 100 in the latter. However, the results are quite similar to the benchmark scenario in both cases.

Alternative measures of product concentration/diversification. In the benchmark model, the Herfindahl index is given in natural logarithms. A simple robustness check consists in using the Herfindahl index in levels. Other concentration/diversification measures may likewise be used. The Theil and Gini indices are the most common alternatives to the Herfindahl index (see Cadot et al. 2013 for details). The underlying logic is the same: a decrease in the index is associated with greater export diversification and vice versa. These three alternatives (the Herfindahl index in levels and both the Theil and Gini indices, also in levels) are considered for the estimation of the baseline empirical model without altering the general results. Obviously, the beta coefficients do not have a direct interpretation as elasticities and differ in magnitude due to natural differences in the values of the indices (see also Table A1). However, the general result of the model, the positive association between exports and exports concentration, still holds.

Different subsamples of destination countries. A natural question that arises is whether the main conclusion holds for different subsamples of destination countries. It would be interesting to analyse this question for several subsamples (e.g. EU countries, Euro Area countries, Latin American countries), but instrument count issues in GMM methods restricts the possibilities. However, a basic distinction between OECD and non-OECD countries can be made. This basic differentiation between developed and developing countries does not alter the results.

\section{DISCUSSION}

This section discusses the main findings of the paper and compares them with the related literature. First, the results are compared with direct precedents. Second, the results are interpreted in broader terms, relating them first of all with other papers that underline country or geographical diversification on trade. In another line of argument, the findings are also related with the literature highlighting the importance of the intensive margin of trade in the evolution of trade flows. At this point, the empirical exercise is repeated taking the share of each destination's exports over total Spanish exports as the dependent variable in the benchmark model. The export share can be decomposed into the extensive and intensive margins of trade as in Hummels and Klenow (2005) to further relate the main finding to this line of reasoning. Finally, some concerns about the results, prospects for future work and tentative policy implications are also briefly outlined. 
The empirical finding of this paper is the positive relationship between Spanish export concentration and export performance by destination market. This finding appears to contradict the results of papers like Funke and Ruhwedel $(2001,2002)$ and Camanho and Romeu (2011), in which export diversification is positively related with export performance. Funke and Ruhwedel $(2001,2002)$ are the closest precedents. These authors adopt an aggregate export demand setting and use GMM dynamic panel techniques to address the endogeneity problem. The reported positive effect of export variety on export performance is 'rather small' (Funke and Ruhwedel (2002, p. 111). Leaving aside the key question of the overall measurement of export variety, the econometric results in both papers are based on extremely narrow panels. Although both studies are multi-country, using GMM techniques with panels of 10 or 15 sections (countries) is controversial (see Roodman, 2009a, b). Camanho and Romeu (2011) use a gravity model to study how product and trading partner diversity influences the export resilience of Latin American countries during the global financial crisis.

Although the econometric estimations were performed on a bilateral basis, the measures of export concentration used in the paper do not distinguish by destination country, i.e. overall diversification versus the rest of the world is used, possibly to circumvent the endogeneity problem. These authors found some evidence that product diversification attenuated the trade collapse, although the same did not occur with geographical diversification.

The key difference of this paper with respect to Funke and Ruhwedel $(2001,2002)$ and Camanho and Romeu (2011) is that export variety is measured versus the rest of the world in the aforementioned papers, whereas in this paper export variety and performance is studied by destination country. When export diversification is quantified from a given country to the rest of the world, product and trading partner (geographical) diversification is mixed. It could be that the overall export diversity of a given country is positively related to overall export performance, while the contrary occurs in each of its destination markets. The bottom line of this reasoning is the convenience of distinguishing between product and geographical diversification. This was done to some extent by Camanho and Romeu (2011), who found that trading partner diversification did not help the trade performance of Latin American countries during the global financial crisis. However, papers such as Evenett and Venables (2002), Brenton and Newfarmer (2007) and Amurgo-Pacheco and Pierola (2008) clearly highlight the importance of geographical diversification in expanding export variety. Evenett and Venables (2002) studied the growth of exports by 23 developing countries for the period 1970-1997, finding that the 'geographical spread of trade' was more important than the introduction of new products. Brenton and Newfarmer (2007) examined the export performance of 99 countries over the period 1995-2004, reporting that the extensive margin was driven far more by trading partner diversification than by the introduction of new products. Amurgo-Pacheco and Pierola (2008) analysed export diversification issues for a group of 24 developed and developing countries for the period 19902005. These authors found that geographic diversification is more important than product diversification at the extensive margin for all countries, but especially for developing ones. More recently, Beverelli et al (2015) estimated the diversification effects of the Trade Facilitation Agreement of the World Trade Organization (WTO). Interestingly, they disentangled two extensive margins, the number of products by destination and the number of destination by product. Their simulation results of implementing the WTO Trade Facilitation Agreement showed that geographical diversification could be greater than product diversification.

The main finding of the present paper may be also related to the literature that underlines the importance of intensifying existing trade relationships. Several of the aforementioned papers, Evenett and Venables (2002), Brenton and Newfarmer (2007) and Amurgo-Pacheco and Pierola 
(2008), also found that the intensive margin accounts for the most part of trade growth. The importance of this margin is also underlined in other papers such as Felbermayr and Kohler (2006), Helpman et al. (2008) and Besedes and Prusa (2011). Easterly et al. (2009) document the high degree of export concentration using manufacturing trade data from 151 countries. Employing the productdestination pair as the unit of analysis, they found that very few product-destination pairs account for a disproportionate share of export volumes. After controlling for the number of products and destinations, Easterly et al. (2009) also found that higher concentration is positively associated with higher trade volumes.

To further investigate this line of reasoning, the empirical model proposed in Section III and estimated in Section IV is changed in the following way. A reasonable alternative to the dependent variable used then (Spanish export value to country $i$ ) is to use the share of destination $i$ 's exports over total Spanish exports, preserving the rest of the model's characteristics. Using the share over total exports as the dependant variable allows its decomposition into the extensive and intensive margins of trade, as in Hummels and Klenow (2005). In the context of this paper, where Spanish exports are analysed by destinations, the extensive and intensive margins respectively have the following definitions for destination $i$ :

$E M_{i}=\frac{\sum_{j \in K^{i}} X_{j}}{\sum_{j} X_{j}}$

$I M_{i}=\frac{\sum_{j \in K^{i}} X_{i j}}{\sum_{j \in K^{i}} X_{j}}$

where $X_{j}=\sum_{i} X_{i j}$ is the Spanish export value of product $j$ and $K^{i}$ stands for destination $i$ 's products set. Hence, the numerator of $E M_{i}$ (and the denominator of $I M_{i}$ ) is the total value of Spanish exports in those products exported to country $i$. Given that the denominator in $E M_{i}$ measures total export value for the entire products set, the extensive margin is a weighted measure of how many of the potential products are actually exported to destination $i$. The intensive margin $I M_{i}$ measures the share of destination $i$ in a specific way, relative to overall exports in $i$ 's products set. Finally, the product of the two margins equals the share of destination $i$ in overall Spanish exports $\left(\right.$ Share $_{i}$ ).

The econometric estimation is repeated successively using $S h a r e_{i}, E M_{i}$ and $I M_{i}$ as the dependant variable (in log values in all cases). In principle, a concentration measure such as the Herfindahl index should be positively related to the intensive margin and negatively related to the extensive margin. It remains to be seen whether the use of shares instead of values for the dependant variable retains the positive correlation with the variable of interest.

[Table 2 here.]

Table 2 shows the results of the benchmark model (System GMM with lags t- 2 to $t-4$ in the firstdifferenced equation and lag t-1 in the levels equation) with the three alternatives for the dependant variable, namely export share, extensive and intensive margins. Beginning with the last variable, the regression with the intensive margin shows the best results, quite similar to the baseline scenario. It is worth noting that both the unrestricted and the restricted coefficients are larger for the log of the Herfindahl index. In contrast, the model with the extensive margin as the dependant variable does not offer good results. The log of the Herfindahl is not at all statistically significant and the Hansen tests indicate specification problems. Interestingly, the model with export share as the dependant variable also works quite well. The Herfindahl index is positively associated with export share, 
although the contemporaneous point estimates are somewhat more imprecise in the unrestricted model.

Thus, the overall impression from Table 2 is that the export share is suited to acting as the dependant variable in the empirical model. Its decomposition offers an economic explanation for the main result of the paper. It appears that the intensification of existing trade relationships, i.e. the intensive margin, may help to explain the positive association between export concentration and export performance by destination country.

Several caveats to the main empirical finding of the paper should be noted here. First, the econometric strategy is based on GMM panel technics, while the use of lagged observations of the endogenous variables as their own instruments have to be taken with caution, especially when the variables show high persistence (see, for instance, Roodman, 2009b). In this respect, it is preferable to interpret the results as correlations rather than causal relationships. Second, the empirical estimations are based on a panel of destinations for a particular exporting country case, namely Spain. An obvious line of future research is to expand the analysis to other case studies as well as to multi-country analysis in order to determine whether the positive relationship between export concentration and export performance by destination is confirmed. However, leaving aside the fact that the country case refers to a developed European country, there is no particular reason to think that it is a special case ${ }^{4}$.

A simple methodological recommendation arises from this paper. Disentangling product and geographical diversification could be important for future research on export diversification, such as its relationship with export performance, the study of its drivers or the analysis of its interrelation with stages of development. The aforementioned paper by Beverelli et al. (2015) is a recent, fine example in this vein.

Finally, some tentative policy implications may be drawn. How to achieve export diversification and even whether this should be a policy priority remain open questions (Cadot et al., 2013). If export diversification is adopted as a policy objective, the results of this paper are in line with recent recommendations underlining the importance of the geographical diversification of trade (Newfarmer et al., 2009).

\section{CONCLUSION}

Most economist would agree with the idea that a country with export diversity is more competitive. However, the literature that specifically studies the link between export diversification and export performance is scarce. Besides, when the issue has been addressed, overall indicators of export diversity (i.e. taking the rest of the world as a single destination) have been used.

This mostly explorative paper moves one step further to analyse what occurs if export diversity is related with export performance at the destination country level. A panel of destinations for a particular exporting country is used for this purpose. The case study is a European developed country, namely Spain. The main finding is the positive relationship between Spanish export

\footnotetext{
${ }^{4}$ Preliminary evidence for other developed European countries (namely, Belgium, France, Germany, Italy, Netherlands and the United Kingdom) shows very similar results. These results are available from the author upon request.
} 
concentration and export performance by destination market, a finding that appears to be quite robust to several specifications.

Is this result at odds with the conventional wisdom that positively relates export diversity and export performance? Not necessarily. The finding of this paper would rather suggest that disentangling product and geographical diversity could be important for future research focusing on the issue of export diversification, a recommendation in line with recent literature.

The result of this paper also needs to be investigated further. For instance, it would be desirable to analyse the research question using a multi-exporter panel. In this case, dealing with joint determination of export diversification and export performance in a three-dimensional panel is a challenge left for future research.

\section{APPENDIX A}

[Tables A1 and A2 here.]

\section{APPENDIX B}

A System GMM model with instruments lagged t-2 to $t-4$ in the first-differenced equation, and one lag for the instruments in the levels equation, is considered the benchmark specification. In this Appendix, the System GMM model is re-estimated with different instrument sets, changing the lag length of the instruments in the first-differenced equation. In the levels equation, only the first lag (for the differenced instruments) is used in all cases, as deeper lags are redundant (Arellano and Bover, 1995).

[Table B1 here.]

The overall impression from Table B1 is that the System GMM estimates are robust to changes in the instrument set. Point estimates of the unrestricted coefficients from Equation (5) are quite similar. Only the results with lags t- 2 to $t-6$ and with the collapsed instruments show some higher coefficients, especially in the case of the contemporaneous Herfindahl index, although less precise in the latter case. The coefficient for the lagged dependent variable is very stable, being slightly lower for the model with the collapsed instruments. On the other hand, all the regressions pass the specification test, with some minor differences to be commented on later. The Arellano-Bond test shows no evidence of serial correlation. The null hypothesis of joint validity of all the instruments is not rejected by the Hansen test in any case, although the case with lags $t-2$ to $t-3$ presents the lowest p-value (0.204). The Difference-in-Hansen test applied to the instruments for the levels equation show high values in all cases. This test is also used to check the validity of additional lags and is not very conclusive regarding the determination of lag length. However, the count of instruments in the System GMM with lags t-2 to t-5 and t-2 to t- 6 becomes a little too high, with 70 and 76 instruments, respectively. Caution regarding the instrument count leads to a preference for models with fewer lags. On the other hand, the results and diagnosis test for the first two System GMM models are very similar, but the Difference-in-Hansen test for the additional lag is very conclusive. The model with 
collapsed instruments in column (5) could be an alternative, but the coefficient estimations present some differences with the other models. The common factor restrictions are clearly accepted in all cases. The minimum distance estimates of the structural parameters are very stable, being somewhat higher for the model with collapsed instruments. In sum, all of these considerations reinforce the choice of the System GMM with lags t-2 to t-4 as the benchmark model, although other instrument sets yield similar results.

\section{APPENDIX C}

This Appendix contains two tables replicating the results of the paper with the robustness checks summarized in Section IV.4. The checks are the following:

Different sample period. See column (1) of Table C1.

Different product classifications. See columns (2) and (5) of Table C1.

Different number of products threshold. See columns (3) and (4) of Table C1

Alternative measures of product concentration/diversification. See columns (1) - (3) of Table C2.

Different subsamples of destination countries. See columns (4) and (5) of Table C2.

All the robustness checks are performed using the same System GMM estimator with lags t-2 to t-4, i.e. the benchmark econometric model. The only exception is the regression for the OECD subsample (column (4) of Table C2), in which the number of sections (OECD countries in the sample) is low: 33. The number of instruments in the benchmark model (62) nearly doubles the number of sections, so the collapsed instrument set is used instead (see Appendix B).

[Tables C1 and C2 here.] 


\section{REFERENCES}

Agosin, M. R., Alvarez, R., and Bravo-Ortega, C. (2012). 'Determinants of export diversification around the World: 1962-2000', The World Economy, 35, pp. 295-315.

Amurgo-Pacheco, A., and Pierola, M. D. (2008). 'Patterns of export diversification in developing countries: Intensive and extensive margins’, World Bank Policy Research Working Paper 4473.

Arellano, M., and Bond, S. (1991). 'Some test of specification for panel data: Monte Carlo evidence and an application to employment equations', Review of Economic Studies, 58, pp. 277-297.

Arellano, M., and Bover, O. (1995). 'Another look at the instrumental variable estimation of errorcomponents models', Journal of Econometrics, 68, pp. 29-51.

Baum, C. F., Schaffer, M. E., and Stillman, S. (2003). 'Instrumental variables and GMM: Estimation and testing', Stata Journal, 3, pp. 1-31.

Bems, R., Johnson, R. C., and Yi, K. M. (2013). 'The Great Trade Collapse', Annual Review of Economics, 5, pp. 375-400.

Besedes, T. and Prusa, T. J. (2011). 'The role of extensive and intensive margins and export growth', Journal of Development Economics, 96, pp. 371-379.

Beverelli, C., Neumueller, S. and Teh, R. (2015). 'Export diversification effects and the WTO Trade Facilitation Agreement', World Development, 76, pp. 293-310.

Blundell, R., and Bond, S. (1998). 'Initial conditions and moment restrictions in dynamic panel data models', Journal of Econometrics, 87, pp. 115-143.

Blundell, R., and Bond, S. (2000). 'GMM Estimation with persistent panel data: an application to production functions', Econometric Reviews, 19, pp. 321-340.

Bond, S. (2002). 'Dynamic panel data methods: a guide to micro data methods and practice', Portuguese Economic Journal, 1, pp. 141-162.

Brenton, P. and Newfarmer, R. (2007) 'Watching more than the discovery channel: export cycles and diversification in development', World Bank Policy Research Working Paper 4302.

Cadot, O., Carrère, C., and Strauss-Kahn, V. (2011a). 'Export diversification: What's behind the hump?', Review of Economics and Statistics, 93, pp. 590-605.

Cadot, O., Carrère, C., and Strauss-Kahn, V. (2011b). 'Trade diversification: drivers and impacts', in M. Jansen, M., R. Peters. and J.M. Salazar-Xirinachs (eds), Trade and Employment: from Myths to Facts, pp. 253-307, Geneva: ILO-EC International Labour Office-European Commission.

Cadot, O., Carrère, C., and Strauss-Khan, V. (2013). 'Trade diversification, income, and growth: What do we know?', Journal of Economic Surveys, 27, pp. 790-812.

Camanho da Costa Neto, N., and Romeu, R. (2011). 'Did export diversification soften the impact of the global financial crisis?', International Monetary Fund Working Paper WP/11/99.

De Benedictis, L., Gallegati, M., and Tamberi, M. (2009). 'Overall trade specialization and economic development: countries diversify’, Review of World Economics, 145, pp. 37-55. 
Dennis, A., and Shepherd, B. (2011). 'Trade facilitation and export diversification', The World Economy, 34, pp. 101-122.

Easterly, W., Reshef, A., and Schwenkenberg, J. (2009). 'The power of exports', World Bank Policy Research Working Paper 5081.

Eurostat (2015). Quality report on European statistics on international trade in goods. Luxembourg: Publications Office of the European Union.

Eurostat (2016). User guide on European statistics on international trade in goods. Luxembourg: Publications Office of the European Union.

Evenett, S. and Venables, A. (2002). 'Export growth in developing countries: market entry and bilateral flows', University of Bern Working Paper.

Felbermayr, G. J. and Kohler, W. (2006). 'Exploring the Intensive and Extensive Margins of World Trade', Review of World Economics, 142, pp. 642-674.

Funke, M., and Ruhwedel, R. (2001). 'Export variety and export performance: empirical evidence from East Asia', Journal of Asian Economics, 12, pp. 493-505.

Funke, M., and Ruhwedel, R. (2002). Export variety and export performance: empirical evidence for the OECD Countries. Review of World Economics, 138(1), 97-114.

Goldstein, M. and Khan, M. S. (1985). 'Income and Price Effects in Foreign Trade', in R. W. Jones and P. B. Kenen (eds), Handbook of International Economics, vol. 2, pp. 1041-1105, Amsterdam: North-Holland.

Imbs, J., and Wacziarg, R. (2003). 'Stages of diversification', American Economic Review, 93, pp. 6386.

Hansen, L.P. (1982). 'Large Sample Properties of Generalized Method of Moments Estimators', Econometrica, 50, pp. 1029-1054.

Helpman, E., Melitz, M. and Rubinstein, Y. (2008). 'Estimating trade flows: trading partners and trading volumes', Quarterly Journal of Economics, 123, pp. 441-487.

Hummels, D., and Klenow, P. J. (2005). 'The variety and quality of a nation's exports', American Economic Review, 95, pp. 704-723.

Klinger, B. and Lederman, D. (2004). 'Discovery and development: an empirical exploration of "new" products', World Bank Policy Research Working Paper 3450.

Klinger, B. and Lederman, D. (2006). Diversification, innovation, and imitation inside the Global Technological Frontier. World Bank Policy Research Working Paper 3872.

Mau, K. (2016). 'Export diversification and income differences reconsidered: the extensive product margin in theory and application', Review of World Economics, 152, pp. 351-381.

Minondo, A. (2011). 'Does comparative advantage explain countries' diversification level?', Review of World Economics, 147, pp. 507-526.

Newfarmer, R., Shaw, W., and Walkenhorst, P. (eds) (2009). Breaking into new markets. Emerging lessons for export diversification. Washington: World Bank. 
Parteka, A. (2010). 'Employment and export specialisation along the development path: Some robust evidence', Review of World Economics, 145, pp. 615-640.

Parteka, A. and Tamberi, M. (2013a). 'What determines export diversification in the development process? Empirical assessment', The World Economy, 36, pp. 807-826.

Parteka, A. and Tamberi, M. (2013b). 'Product diversification, relative specialisation and economic development: import export analysis', Journal of Macroeconomics, 38, pp. 121-135.

Regolo, J. (2013). 'Export diversification: How much does the choice of the trading partner matter?', Journal of International Economics, 91, pp. 329-342.

Roodman, D. (2009a). 'How to do xtabond2: An introduction to difference and system GMM in Stata', Stata Journal, 9, pp. 86-136.

Roodman, D. (2009b). 'A note on the theme of too many instruments', Oxford Bulletin of Economics and Statistics, 71, pp. 135-158.

Sawyer, W. C. and Sprinkle, R. L. (1996). 'The demand for imports and exports in the US: a survey', Journal of Economics and Finance, 20, pp. 147-178.

Sawyer, W.C. and Sprinkle, R. L. (1999). The Demand for Imports and Exports in the World Economy. Ashgate: Aldershot.

Windmeijer, F. (2005). 'A finite sample correction for the variance of linear efficient two-step GMM estimators', Journal of Econometrics, 126, pp. 25-51.

Wooldridge, J. M. (2010). Econometric analysis of cross section and panel data, 2nd ed. Cambridge: MIT Press.

Yu, D. (2008). 'The Harmonized System. Amendments and their impact on WTO members' schedules', World Trade Organization Economic Research and Statistics Division, Staff Working Paper ERSD-2008-02. 


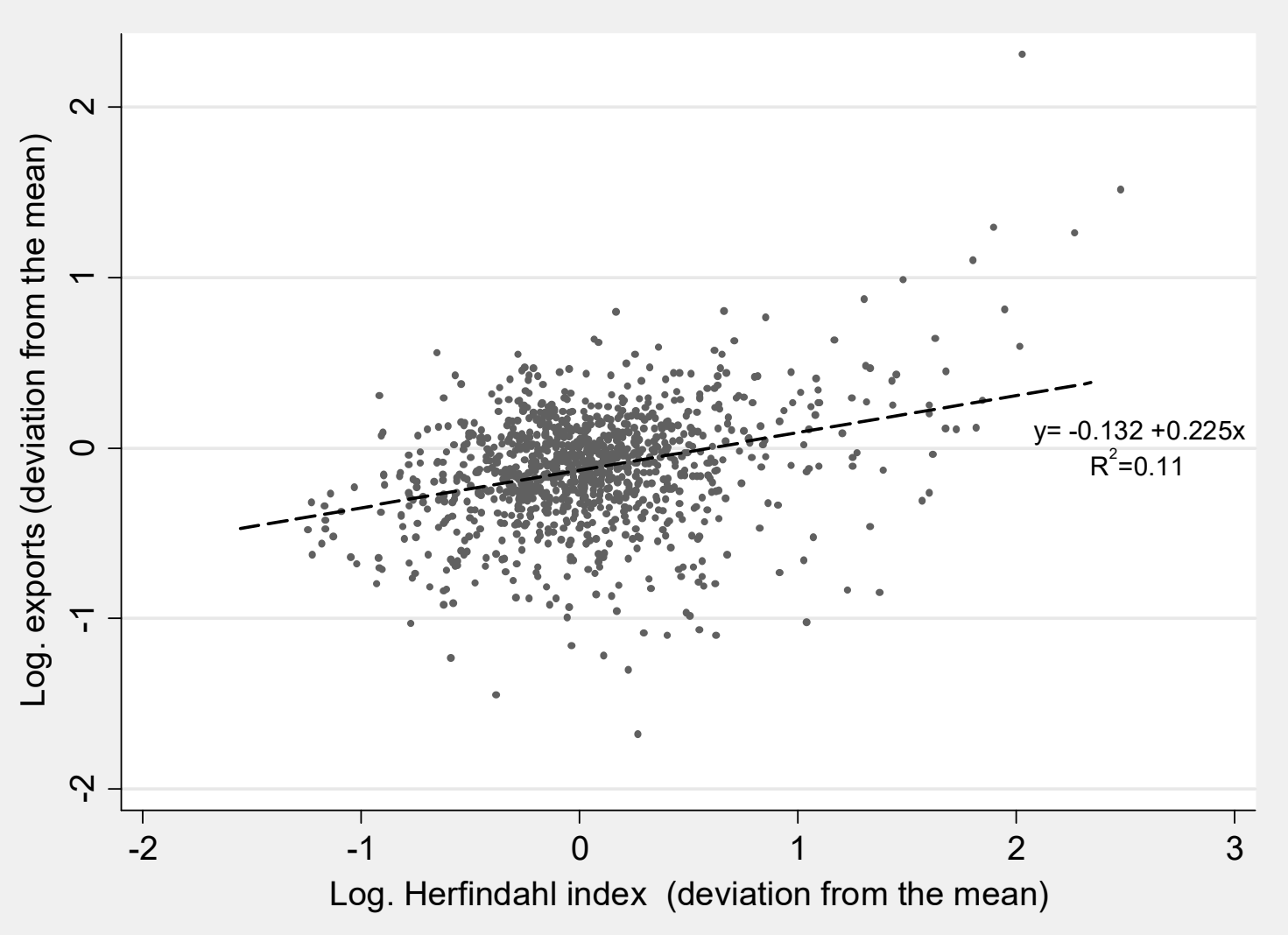

Fig. 1 Logarithm of Spanish exports versus logarithm of the Herfindahl index at the destination country level (deviations from the country mean) 
TABLE 1

Baseline results

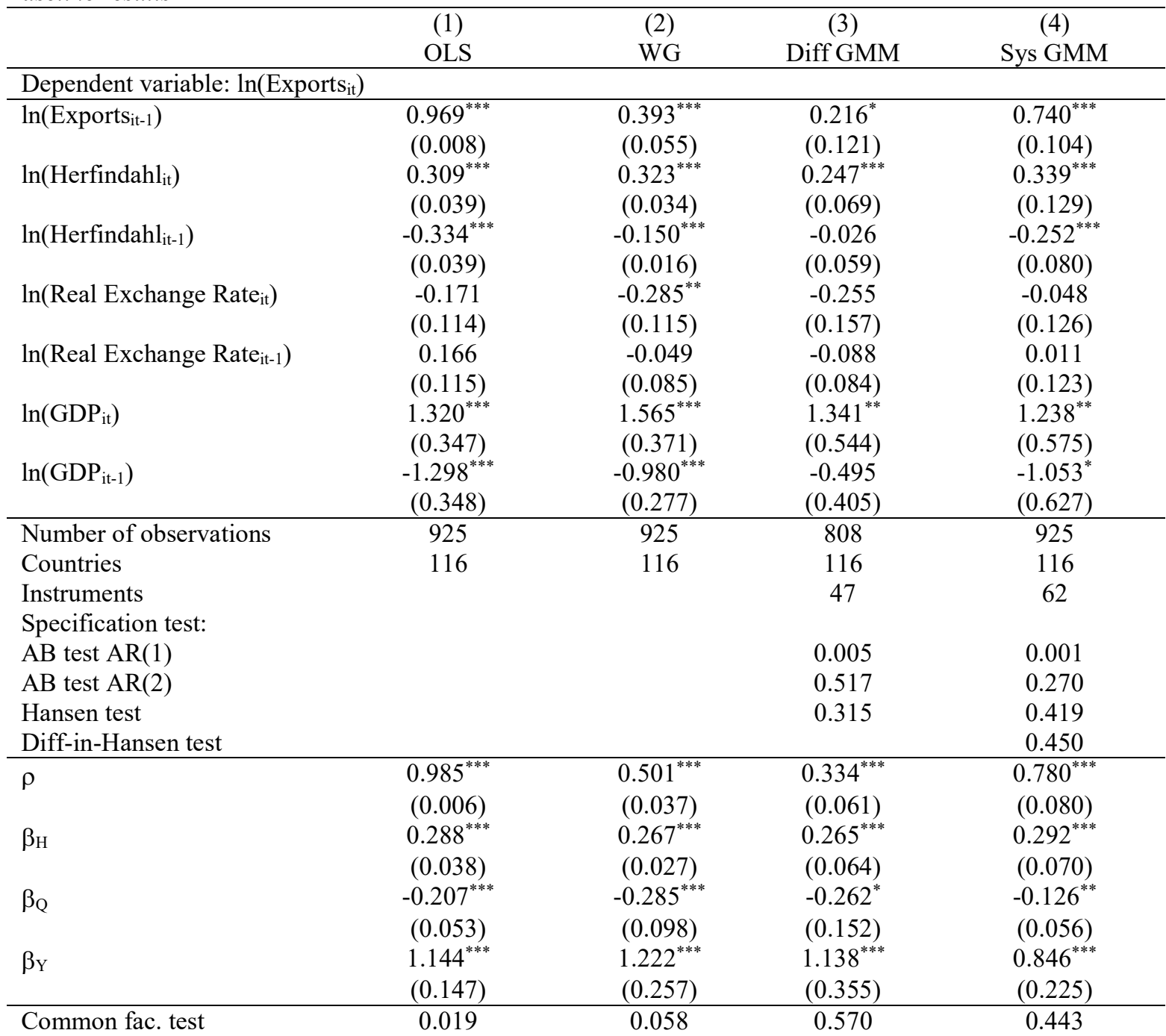

Notes. The estimators are (pooled) Ordinary Least Squares, Within Groups, Difference GMM (lags t-2 to t-4) and System GMM (lags $\mathrm{t}-2$ to $\mathrm{t}-4$ in the first-differenced equation and lag $\mathrm{t}-1$ in the levels equation). In the GMM models, a two-step procedure is used with Windmeijer (2005) robust errors. Time dummies are included in all the regressions. In the specification and common factor test, $\mathrm{p}$ values are reported. AB test AR(1)/AR(2): Arellano-Bond test for first- and second-order serial correlation in the first-differenced equation (null hypothesis: no serial correlation). The Hansen test reports the p-values for the null hypothesis of joint validity of all instruments. The Diff-in-Hansen test checks the validity of the instruments for the levels equation (null hypothesis: joint validity of the full set of instruments). The lower part of the table shows the structural coefficients obtained by minimum distance estimation. Common fac. test: minimum distance test of the common factor restrictions (null hypothesis: the common factor restrictions are valid). $*, * *$, and $* * *$ denote significance at the 10,5 and $1 \%$ level, respectively. 
TABLE 2

Extensive and Intensive margins

\begin{tabular}{|c|c|c|c|}
\hline & $\begin{array}{l}(1) \\
\text { Share }\end{array}$ & $\begin{array}{c}\text { (2) } \\
\text { Extensive Margin }\end{array}$ & $\begin{array}{c}\text { (3) } \\
\text { Intensive Margin }\end{array}$ \\
\hline Dependent variable: & $\ln \left(\right.$ Share $\left._{i t}\right)$ & $\ln \left(\right.$ Extensive Margin $\left._{\mathrm{it}}\right)$ & $\ln \left(\right.$ Intensive Margin $\left._{\mathrm{it}}\right)$ \\
\hline $\ln \left(\right.$ Share $\left._{\mathrm{it}-1}\right)$ & $\begin{array}{l}0.723^{* * *} \\
(0.094)\end{array}$ & & \\
\hline $\ln \left(\right.$ Extensive Margin $\left._{\text {it-1 }}\right)$ & & $\begin{array}{l}0.661^{* * *} \\
(0.088)\end{array}$ & \\
\hline $\ln \left(\right.$ Intensive Margin $\left._{\text {it- } 1}\right)$ & & & $\begin{array}{l}0.735^{* * *} \\
(0.076)\end{array}$ \\
\hline $\ln \left(\right.$ Herfindahl $\left._{\mathrm{it}}\right)$ & $\begin{array}{l}0.334^{* *} \\
(0.132)\end{array}$ & $\begin{array}{l}-0.064 \\
(0.040)\end{array}$ & $\begin{array}{l}0.410^{* * * *} \\
(0.128)\end{array}$ \\
\hline $\ln \left(\right.$ Herfindahl $\left._{\mathrm{it}-1}\right)$ & $\begin{array}{c}-0.244^{* * * *} \\
(0.080)\end{array}$ & $\begin{array}{c}0.015 \\
(0.015)\end{array}$ & $\begin{array}{c}-0.274^{* * *} \\
(0.083)\end{array}$ \\
\hline $\ln \left(\right.$ Real Exchange Rate $\left._{i t}\right)$ & $\begin{array}{l}-0.076 \\
(0.161)\end{array}$ & $\begin{array}{l}-0.055 \\
(0.034)\end{array}$ & $\begin{array}{l}-0.050 \\
(0.112)\end{array}$ \\
\hline $\ln \left(\right.$ Real Exchange Rate $\left._{i t-1}\right)$ & $\begin{array}{c}0.038 \\
(0.157)\end{array}$ & $\begin{array}{c}0.046 \\
(0.036)\end{array}$ & $\begin{array}{c}0.019 \\
(0.111)\end{array}$ \\
\hline $\ln \left(\mathrm{GDP}_{\mathrm{it}}\right)$ & $\begin{array}{l}1.093^{* *} \\
(0.430)\end{array}$ & $\begin{array}{c}0.185 \\
(0.163)\end{array}$ & $\begin{array}{l}0.659^{*} \\
(0.400)\end{array}$ \\
\hline $\ln \left(\mathrm{GDP}_{\mathrm{it}-1}\right)$ & $\begin{array}{l}-0.897^{*} \\
(0.458)\end{array}$ & $\begin{array}{c}-0.156 \\
(0.162) \\
\end{array}$ & $\begin{array}{l}-0.483 \\
(0.413) \\
\end{array}$ \\
\hline Number of observations & 925 & 925 & 925 \\
\hline Countries & 116 & 116 & 116 \\
\hline Instruments & 62 & 62 & 62 \\
\hline Specification test: & & & \\
\hline $\mathrm{AB}$ test $\mathrm{AR}(1)$ & 0.001 & 0.000 & 0.000 \\
\hline $\mathrm{AB}$ test $\mathrm{AR}(2)$ & 0.268 & 0.745 & 0.209 \\
\hline Hansen test & 0.172 & 0.008 & 0.335 \\
\hline Diff-in-Hansen test & 0.261 & 0.032 & 0.463 \\
\hline$\rho$ & $\begin{array}{l}0.748^{* * *} \\
(0.079)\end{array}$ & $\begin{array}{l}0.656^{* * *} \\
(0.087)\end{array}$ & $\begin{array}{l}0.722^{* * *} \\
(0.069)\end{array}$ \\
\hline$\beta_{\mathrm{H}}$ & $\begin{array}{l}0.322^{* * *} \\
(0.083)\end{array}$ & $\begin{array}{l}-0.009 \\
(0.021)\end{array}$ & $\begin{array}{l}0.350^{* * *} \\
(0.107)\end{array}$ \\
\hline$\beta_{\mathrm{Q}}$ & $\begin{array}{c}-0.132^{* *} \\
(0.054)\end{array}$ & $\begin{array}{c}-0.034^{* * *} \\
(0.011)\end{array}$ & $\begin{array}{c}-0.110^{* *} \\
(0.043)\end{array}$ \\
\hline$\beta_{\mathrm{Y}}$ & $\begin{array}{l}0.778^{* * *} \\
(0.146)\end{array}$ & $\begin{array}{l}0.102^{* * *} \\
(0.362)\end{array}$ & $\begin{array}{c}-0.638^{* * *} \\
(0.076)\end{array}$ \\
\hline Common fac. test & 0.724 & 0.362 & 0.849 \\
\hline
\end{tabular}

Notes. In all cases, the estimator is System GMM with lags t-2 to t-4 in the first-differenced equation and lag t-1 in the levels equation. A two-step procedure is used with Windmeijer (2005) robust errors. Time dummies are included in all the regressions. In the specification and common factor test, p-values are reported. AB test AR(1)/AR(2): Arellano-Bond test for first- and second-order serial correlation in the first-differenced equation (null hypothesis: no serial correlation). The Hansen test reports the p-values for the null hypothesis of joint validity of all instruments. The Diff-in-Hansen test checks the validity of the instruments for the levels equation (null hypothesis: joint validity of the full set of instruments). The lower part of the table shows the structural coefficients obtained by minimum distance estimation. Common fac. test: minimum distance test of the common factor restrictions (null hypothesis: the common factor restrictions are valid). See text for more details. Standard errors are in parentheses under coefficient estimates. $* * *$, and $* * *$ denote significance at the 10,5 and $1 \%$ level, respectively. 
TABLE A1

Descriptive Statistics with between and within variation

\begin{tabular}{|c|c|c|c|c|c|c|}
\hline Variable & Variation & Mean & Std. deviation & Min. & Max. & Obs. \\
\hline \multirow[t]{3}{*}{$\ln \left(\right.$ Exports $\left._{\mathrm{it}}\right)$} & overall & 18.794 & 1.979 & 14.190 & 24.190 & obs. $=1514$ \\
\hline & between & & 1.957 & 14.953 & 24.014 & countries $=128$ \\
\hline & within & & 0.353 & 15.968 & 21.079 & $\overline{\mathrm{T}}=11.82$ \\
\hline \multirow[t]{3}{*}{ Herfindahl $_{\text {it }}$} & overall & 0.057 & 0.085 & 0.003 & 0.878 & obs. $=1514$ \\
\hline & between & & 0.064 & 0.004 & 0.536 & countries $=128$ \\
\hline & within & & 0.056 & -0.242 & 0.760 & $\overline{\mathrm{T}}=11.82$ \\
\hline \multirow[t]{3}{*}{ Ln(Herfindahl $\left.{ }_{\text {it }}\right)$} & overall & -3.350 & 0.899 & -5.811 & -0.130 & obs. $=1514$ \\
\hline & between & & 0.750 & -5.505 & -0.715 & countries $=128$ \\
\hline & within & & 0.499 & -4.677 & -0.440 & $\overline{\mathrm{T}}=11.82$ \\
\hline \multirow[t]{3}{*}{$\ln \left(\right.$ Real Exchange Rate $\left._{\text {it }}\right)$} & overall & 2.720 & 2.774 & -3.167 & 23.106 & obs. $=1514$ \\
\hline & between & & 2.732 & -1.338 & 10.037 & countries $=128$ \\
\hline & within & & 0.632 & -4.233 & 22.040 & $\overline{\mathrm{T}}=11.82$ \\
\hline \multirow[t]{3}{*}{$\operatorname{Ln}\left(G^{\prime} P_{i t}\right)$} & overall & 24.587 & 1.959 & 20.103 & 30.259 & obs. $=1514$ \\
\hline & between & & 1.963 & 20.279 & 30.185 & countries $=128$ \\
\hline & within & & 0.171 & 23.545 & 25.306 & $\overline{\mathrm{T}}=11.82$ \\
\hline \multirow[t]{3}{*}{ Theil $_{\text {it }}$} & overall & 2.292 & 0.551 & 0.996 & 5.651 & obs. $=1514$ \\
\hline & between & & 0.404 & 1.532 & 3.660 & countries $=128$ \\
\hline & within & & 0.378 & 1.015 & 5.438 & $\overline{\mathrm{T}}=11.82$ \\
\hline \multirow[t]{3}{*}{ Gini $_{\text {it }}$} & overall & 0.878 & 0.037 & 0.715 & 0.989 & obs. $=1514$ \\
\hline & between & & 0.027 & 0.806 & 0.966 & countries $=128$ \\
\hline & within & & 0.025 & 0.755 & 1.002 & $\overline{\mathrm{T}}=11.82$ \\
\hline \multirow[t]{3}{*}{$\ln \left(\right.$ Share $\left._{i t}\right)$} & overall & -6.865 & 1.971 & -11.563 & -1.612 & obs. $=1514$ \\
\hline & between & & 1.956 & -10.669 & -1.647 & countries $=128$ \\
\hline & within & & 0.316 & -9.822 & -4.566 & $\overline{\mathrm{T}}=11.82$ \\
\hline \multirow[t]{3}{*}{$\ln \left(\right.$ Extensive Margin $\left._{\mathrm{it}-1}\right)$} & overall & -0.656 & 0.493 & -2.648 & -0.009 & obs. $=1514$ \\
\hline & between & & 0.486 & -2.011 & -0.017 & countries $=128$ \\
\hline & within & & 0.121 & -1.704 & -0.171 & $\overline{\mathrm{T}}=11.82$ \\
\hline \multirow[t]{3}{*}{$\ln \left(\right.$ Intensive Margin $\left._{\mathrm{it}-1}\right)$} & overall & -6.209 & 1.578 & -9.752 & -1.590 & obs. $=1514$ \\
\hline & between & & 1.554 & -8.978 & -1.630 & countries $=128$ \\
\hline & within & & 0.292 & -8.480 & -3.812 & $\overline{\mathrm{T}}=11.82$ \\
\hline
\end{tabular}

Note. Descriptive statistics are computed with the largest number of countries and the longest sample period used in the regressions. 
TABLE A2

List of countries

\begin{tabular}{|c|c|c|c|}
\hline Albania & Dominican Republic & Korea, Rep. & Romania \\
\hline Algeria & Ecuador & Kuwait & Russian Federation \\
\hline Andorra & Egypt & Latvia & San Marino \\
\hline Angola & El Salvador & Lebanon & Saudi Arabia \\
\hline Argentina & Equatorial Guinea & Libya & Senegal \\
\hline Aruba & Estonia & Lithuania & Singapore \\
\hline Australia & Ethiopia & Luxembourg & Slovak Republic \\
\hline Austria & Finland & Macao & Slovenia \\
\hline Bahamas & France & Macedonia & South Africa \\
\hline Bahrain & Gabon & Madagascar & Sri Lanka \\
\hline Bangladesh & Gambia & Malaysia & Sudan \\
\hline Barbados & Georgia & Mali & Sweden \\
\hline Belarus & Germany & Malta & Switzerland \\
\hline Belgium & Ghana & Mauritania & Syrian, Arab Republic \\
\hline Benin & Greece & Mauritius & Tanzania \\
\hline Bolivia & Guatemala & Mexico & Thailand \\
\hline Bosnia and Herzegovina & Guinea & Moldova & Togo \\
\hline Brazil & Haiti & Morocco & Trinidad and Tobago \\
\hline Bulgaria & Honduras & Mozambique & Tunisia \\
\hline Burkina Faso & Hong Kong & Namibia & Turkey \\
\hline Cabo Verde & China & Netherlands & Uganda \\
\hline Cameroon & Hungary & New Zealand & Ukraine \\
\hline Canada & Iceland & Nicaragua & United Arab Emirates \\
\hline Chile & India & Nigeria & United Kingdom \\
\hline China & Indonesia & Norway & United States \\
\hline Colombia & Iran, Islamic Rep. & Oman & Uruguay \\
\hline Congo, Rep. & Ireland & Pakistan & Venezuela, RB \\
\hline Costa Rica & Israel & Panama & Vietnam \\
\hline Cote d'Ivoire & Italy & Paraguay & Yemen, Rep. \\
\hline Croatia & Japan & Peru & Zimbabwe \\
\hline Cyprus & Jordan & Philippines & \\
\hline Czech Republic & Kazakhstan & Poland & \\
\hline Denmark & Kenya & Portugal & \\
\hline
\end{tabular}

Note. The table shows the largest list of countries used in the regressions. 
TABLE B1

System GMM with different instrument sets

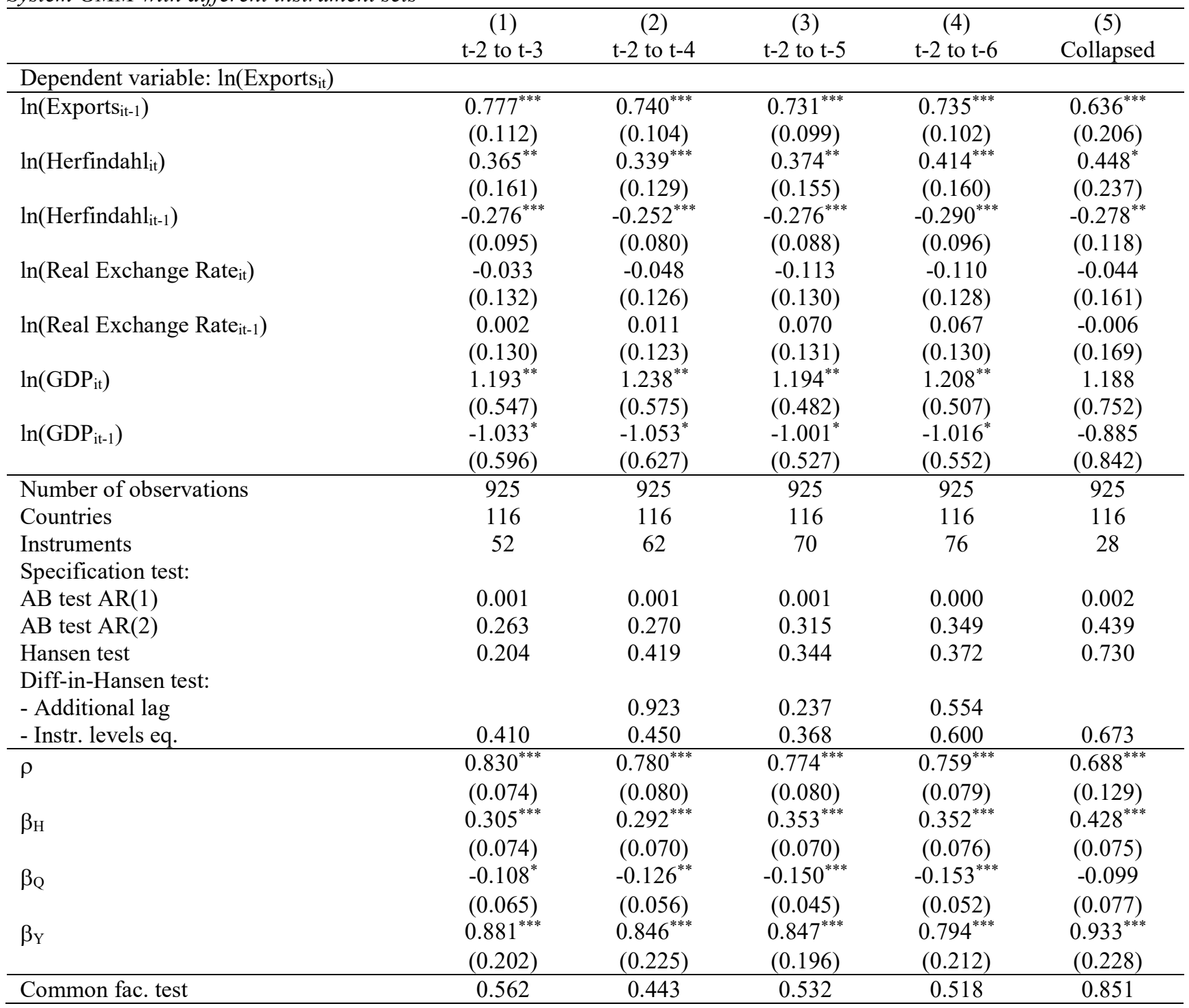

Notes. In all cases, the estimator is System GMM, with different lag structures in the first-differenced equation and lag t-1 in the levels equation. A two-step procedure is used with Windmeijer (2005) robust errors. Time dummies are included in all the regressions. In the specification and common factor test, p-values are reported. AB test AR(1)/AR(2): Arellano-Bond test for first- and second-order serial correlation in the first-differenced equation (null hypothesis: no serial correlation). The Hansen test reports the p-values for the null hypothesis of joint validity of all instruments. The Diff-in-Hansen test checks the validity of a subset of instruments (null hypothesis: joint validity of the full set of instruments). The lower part of the table shows the structural coefficients obtained by minimum distance estimation. Common fac. test: minimum distance test of the common factor restrictions (null hypothesis: the common factor restrictions are valid). See text for more details.

Standard errors are in parentheses under coefficient estimates. *, $* *$, and $* * *$ denote significance at the 10,5 and $1 \%$ level, respectively. 
TABLE C1

Robustness checks

\begin{tabular}{|c|c|c|c|c|c|}
\hline & $\begin{array}{c}(1) \\
1999-11\end{array}$ & $\begin{array}{c}(2) \\
\text { Current HS }\end{array}$ & $\begin{array}{c}(3) \\
50 \mathrm{HS}\end{array}$ & $\begin{array}{c}(4) \\
200 \mathrm{HS}\end{array}$ & $\begin{array}{c}5) \\
\text { CN8 }\end{array}$ \\
\hline \multicolumn{6}{|c|}{ Dependent variable: $\ln \left(\right.$ Exports $\left._{i t}\right)$} \\
\hline \multirow[t]{2}{*}{$\ln \left(\right.$ Exports $\left._{\mathrm{it}-1}\right)$} & $0.753^{* * *}$ & $0.786^{* * *}$ & $0.694^{* * *}$ & $0.795^{* * *}$ & $0.694^{* * *}$ \\
\hline & $(0.072)$ & $(0.101)$ & $(0.092)$ & $(0.095)$ & $(0.120)$ \\
\hline \multirow[t]{2}{*}{$\ln \left(\right.$ Herfindahl $\left._{\mathrm{it}}\right)$} & $0.237^{* *}$ & $0.345^{* * *}$ & $0.468^{* * *}$ & $0.253^{* *}$ & $0.278^{* *}$ \\
\hline & $(0.113)$ & $(0.127)$ & $(0.129)$ & $(0.098)$ & $(0.127)$ \\
\hline \multirow[t]{2}{*}{$\ln \left(\right.$ Herfindahl $\left._{\mathrm{it}-1}\right)$} & $-0.230^{* * *}$ & $-0.261^{* * * *}$ & $-0.280^{* * *}$ & $-0.218^{* * *}$ & $-0.213^{* * *}$ \\
\hline & $(0.074)$ & $(0.076)$ & $(0.070)$ & $(0.067)$ & $(0.072)$ \\
\hline \multirow[t]{2}{*}{$\ln \left(\right.$ Real Exchange Rate $\left.{ }_{i t}\right)$} & -0.151 & -0.107 & -0.117 & -0.141 & -0.104 \\
\hline & $(0.093)$ & $(0.108)$ & $(0.097)$ & $(0.139)$ & $(0.117)$ \\
\hline \multirow[t]{2}{*}{$\ln ($ Real Exchange Rate it-1 $)$} & 0.118 & 0.073 & 0.083 & 0.116 & 0.070 \\
\hline & $(0.094)$ & $(0.106)$ & $(0.091)$ & $(0.139)$ & $(0.117)$ \\
\hline \multirow[t]{2}{*}{$\ln \left(\mathrm{GDP}_{\mathrm{it}}\right)$} & $1.243^{* * *}$ & $1.334^{* * *}$ & $1.269^{* *}$ & $1.243^{* * *}$ & $1.300^{* *}$ \\
\hline & $(0.297)$ & $(0.501)$ & $(0.519)$ & $(0.464)$ & $(0.558)$ \\
\hline \multirow[t]{2}{*}{$\ln \left(\mathrm{GDP}_{\mathrm{it}-1}\right)$} & $-1.061^{* * *}$ & $-1.186^{* *}$ & $-1.017^{*}$ & $-1.107^{* *}$ & $-1.077^{*}$ \\
\hline & $(0.325)$ & $(0.540)$ & $(0.543)$ & $(0.483)$ & $(0.618)$ \\
\hline Number of observations & 1375 & 925 & 1021 & 797 & 949 \\
\hline Countries & 116 & 116 & 128 & 100 & 119 \\
\hline Instruments & 98 & 62 & 62 & 62 & 62 \\
\hline \multicolumn{6}{|l|}{ Specification test: } \\
\hline $\mathrm{AB}$ test $\mathrm{AR}(1)$ & 0.000 & 0.001 & 0.000 & 0.002 & 0.001 \\
\hline $\mathrm{AB}$ test $\mathrm{AR}(2)$ & 0.128 & 0.305 & 0.167 & 0.776 & 0.239 \\
\hline Hansen test & 0.343 & 0.451 & 0.193 & 0.435 & 0.198 \\
\hline Diff-in-Hansen test & 0.519 & 0.517 & 0.479 & 0.730 & 0.150 \\
\hline \multirow[t]{2}{*}{$\rho$} & $0.839^{* * *}$ & $0.849^{* * *}$ & $0.671^{* * *}$ & $0.872^{* * *}$ & $0.769^{* * *}$ \\
\hline & $(0.056)$ & $(0.063)$ & $(0.069)$ & $(0.084)$ & $(0.091)$ \\
\hline \multirow{2}{*}{$\beta_{\mathrm{H}}$} & $0.356^{* * *}$ & $0.285^{* * *}$ & $0.377^{* * * *}$ & $0.277^{* * * *}$ & $0.285^{* * *}$ \\
\hline & $(0.068)$ & $(0.062)$ & $(0.071)$ & $(0.055)$ & $(0.060)$ \\
\hline \multirow[t]{2}{*}{$\beta_{\mathrm{Q}}$} & $-0.139^{*}$ & $-0.133^{* *}$ & $-0.117^{* * *}$ & $-0.140^{* * *}$ & $-0.106^{* *}$ \\
\hline & $(0.035)$ & $(0.056)$ & $(0.044)$ & $(0.044)$ & $(0.051)$ \\
\hline \multirow[t]{2}{*}{$\beta_{Y}$} & $1.023^{* * *}$ & $0.972^{* * *}$ & $0.771^{* * *}$ & $0.939^{* * *}$ & $0.982^{* * *}$ \\
\hline & $(0.153)$ & $(0.246)$ & $(0.161)$ & $(0.277)$ & $(0.243)$ \\
\hline Common fac. test & 0.126 & 0.454 & 0.734 & 0.554 & 0.520 \\
\hline
\end{tabular}

Notes. In all cases, the estimator is System GMM with lags t-2 to t-4 in the first-differenced equation and lag t- 1 in the levels equation. A two-step procedure is used with Windmeijer (2005) robust errors. Time dummies are included in all the regressions. In the specification and common factor test, p-values are reported. AB test AR(1)/AR(2): Arellano-Bond test for first- and second-order serial correlation in the first-differenced equation (null hypothesis: no serial correlation). The Hansen test reports the p-values for the null hypothesis of joint validity of all instruments. The Diff-in-Hansen test checks the validity of the instruments for the levels equation (null hypothesis: joint validity of the full set of instruments). The lower part of the table shows the structural coefficients obtained by minimum distance estimation. Common fac. test: minimum distance test of the common factor restrictions (null hypothesis: the common factor restrictions are valid). See text for more details.

Standard errors are in parentheses under coefficient estimates. ${ }^{*}, * *$, and $* * *$ denote significance at the 10,5 and $1 \%$ level, respectively. 
TABLE C2

Robustness checks

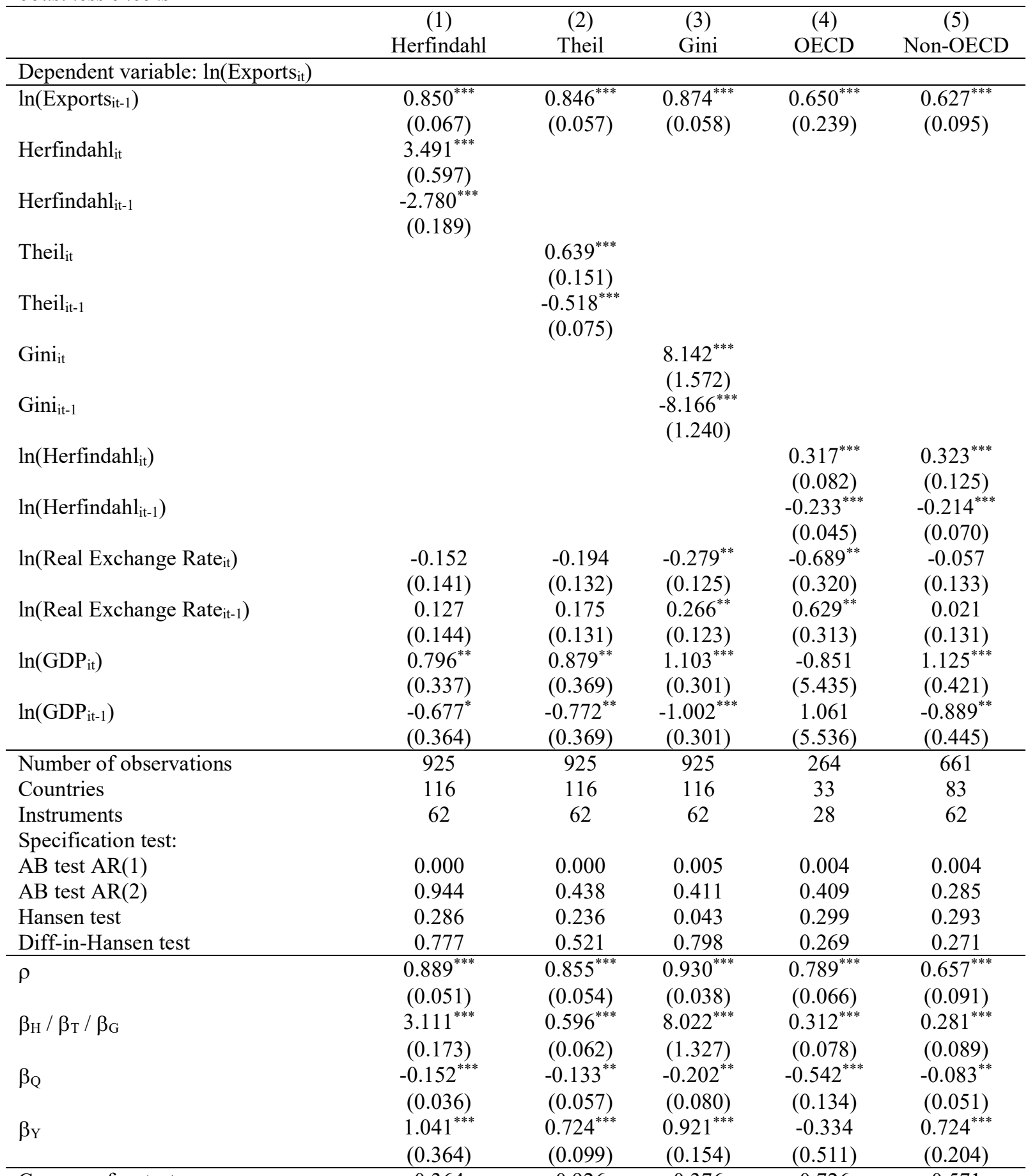

\begin{tabular}{lccccc} 
Common fac. test & 0.364 & 0.926 & 0.376 & 0.726 & 0.571 \\
\hline Notes. In all cases, the estimator is System GMM with lags t-2 to t-4 in the first-differenced equation and lag t-1 in the levels equation. A two-step
\end{tabular} procedure is used with Windmeijer (2005) robust errors. Time dummies are included in all the regressions. In the specification and common factor test, p-values are reported. $\mathrm{AB}$ test $\mathrm{AR}(1) / \mathrm{AR}(2)$ : Arellano-Bond test for first- and second-order serial correlation in the first-differenced equation (null hypothesis: no serial correlation). The Hansen test reports the p-values for the null hypothesis of joint validity of all instruments. The Diff-in-Hansen test checks the validity of the instruments for the levels equation (null hypothesis: joint validity of the full set of instruments). The lower part of the table shows the structural coefficients obtained by minimum distance estimation. Common fac. test: minimum distance test of the common factor restrictions (null hypothesis: the common factor restrictions are valid). See text for more details. Standard errors are in parentheses under coefficient estimates. *, **, and $* * *$ denote significance at the 10,5 and $1 \%$ level, respectively. 